Research

\title{
Prevalence, Identification and Geographical Distribution of Eimeria spp. in Wild Rodents in Malang, East Java
}

\author{
Reza Yesica'*, Shelly Kusumarini R.', Ida Bagus Gde Rama Wisesa' \\ 'Laboratory of Veterinary Parasitology Faculty of Veterinary Medicine, Universitas Brawijaya, \\ Jl. Puncak Dieng Ekslusif, Kelurahan Kalisongo, Kecamatan Dau, \\ Kabupaten Malang, East Java 65151, Indonesia \\ *Corresponding author: rezayesica@ub.ac.id \\ Submitted April 17, 2021 Accepted May 12, 2021
}

\begin{abstract}
Eimeria is a genus of apicomplexan parasites that infected various species and known as the enteric monoxenous coccidian. This study aims to determine the prevalence, identification and geographical distribution study of gastrointestinal protozoa Eimeria spp. in wild rodents in Malang city, East Java. A total of 74 rodents were collected from different part of Malang, using single live traps. Rats were euthanized with ketamine and xylazine. Samples of stools were taken from gastrointestinal tract. Coprological procedure using floatation method lead to the demonstration of Eimeria spp. oocysts in the faecal samples examined at 400 and 1000 magnifications of light microscope. Cultivation in dichromate potassium $2.5 \%$ was carried out for all of coccidian positive samples. The identification is based on morphology and morphometry. Eimeria identification data was analyzed descriptively, while the analysis of species and gender of rodents on prevalence used chi square. Result, the prevalence of Eimeria spp. in Malang is 11 (14.9\%). It was suggesting coccidiosis caused by Eimeria nieschulzi. In addition, Chi square analysis showed that species of rats did not have a significant relationship $(P>0.05)$ to the incidence of Eimeria infection, however it has significant correlation between gender of rats and Eimeria infection $(P<0.05)$. The geographical of Eimeria spp. spots were showed in 8 Sampling area, in Lowokwaru, Klojen, Kedung kandang and Sukun sub district._Findings of this study showed that wild rodents in Malang city are infected with intestinal coccidian parasites.
\end{abstract}

Keywords: Eimeria spp, Malang, rodents.

\begin{abstract}
ABSTRAK
Eimeria adalah salah satu genus dari parasit Apicomplexan yang menginfeksi berbagai macam spesies dan merupakan monoxenous coccidian. Penelitian ini bertujuan untuk menghitung prevalensi, mengidentifikasi dan mempelajari distribusi geografis protozoa Eimeria spp. pada tikus liar di Kota Malang, Jawa Timur. Sebanyak 74 rodensia ditangkap dari berbagai lokasi yang berbeda di Kota Malang, menggunakan jebakan tunggal. Tikus yang tertangkap di euthanasia menggunakan ketamine dan xylazine. Sampel feses diambil dari saluran pencernaan. Pemeriksaan feses menggunakan metode apung untuk mendeteksi ookista Eimeria spp. dengan menggunakan mikroskop perbesaran 400 dan 1000. Sporulasi dilakukan pada sampel yang positif dan feses direndam pada potassium dichromate $2.5 \%$ Identifikasi dilakukan berdasarkan morfologi dan morfometri Eimeria spp. Data yang diperoleh diolah secara deskriptif, dan dilakukan analisis terhadap hubungan antara species dan gender tikus terhadap infeksi Eimeria spp. menggunakan Uji Chi square. Hasil penelitian ini menunjukan prevalensi Eimeria spp. pada tikus liar di Kota Malang sebesar 11 (14.9\%). Parasit tersebut diduga Eimeria nieschulzi yang banyak menyerang rodensia. Analisis data menggunakan uji chi-square diperoleh hasil tidak ada hubungan signifikan antara infeksi Eimeria dengan spesies tikus liar yang tertangkap $(P>0.05)$, tetapi didapatkan hasil korelasi antara infeksi Eimeria dengan jenis kelamin tikus liar $(P<0.05)$. Distribusi geografis infeksi Eimeria tersebar di 8 lokasi pengambilan sampel, yaitu Kecamatan Lowokwaru, Klojen, Kedung kandang dan Sukun. Kesimpulan dari penelitian ini ialah tikus liar di Kota Malang terinfeksi oleh parasit coccidian Eimeria.
\end{abstract}

Kata Kunci : Eimeria spp, Malang, rodensia. 


\section{INTRODUCTION}

Coccidia is one of protozoan parasites from Apicomplexa phylum and pathogenic species to animal or human. One of them, genus Eimeria is monoxenous coccidian, primarily infect single host in their life cycle (Girard et.al., 2016). Eimeria is also known as obligate intracellular parasites that have significant roles to medical or veterinary importance (Wiedmer et.al., 2020). Eimeria predilection commonly in the intestinal tract, however some species are also found in the liver of rabbit or kidney of goose (Chen et.al., 2013). This protozoa can be found almost in all species of vertebrates and highly diverse with estimates of the genus more than a thousand species (Blake, 2015). The most studied protozoa are those infecting livestock such as cattle, swine, goat, sheep or poultry, but more than thirty percent of the described species infects rodents (Zhao and Duszynski, 2001).

Malang is a densely populated city in East Java (Soseco, 2018). In this city, rodents can be found in human residence, market place, field, park or in landfill areas. They are live in close association with humans in order to gain their basic needs such as food and shelter. Rodents represent almost one half of all mammal species (Mácová, 2013). Rodents consist of more than thousand species divided into 17 subfamilies (Jansa and Weksler, 2004). Rodents are also involve in the spread of generous diseases worldwide. They represent common hosts for various parasites, such as helminthiais, blood protozoan, coccidians or ectoparasites. More than 400 species of Eimeria have been infected rodents (Duszynski and Upton, 2001).

Commonly, coccidian parasites found infecting rats include E. nieschulzi, Eimeria miyairii, , and E. separate (Backer, 2007). Chapman et.al. (2013) described identification of Eimeria species using morphology or morphometry of the sporulated oocyst and microscopical observation of oocysts in faeces during the patent period of infection. Sporulated oocysts of Eimeria species can usually be differentiated from other coccidia by the presence of four sporocysts, each containing two sporozoites. Further, the identification of oocyst should be sporulated under specific conditions (Jarquin-Diaz et.al., 2019).

In other study, Vermeulen et.al. (2016), the descriptions of Eimeria species also draw on information such as host species and geographical distribution. Parasitological biodiversity and information from studies of parasites help to understand the biosphere from the global view point (Brooks \& Hoberg, 2000). To development of knowledge this study represents the first Eimeria isolate from rodents in Malang city.

\section{MATERIAL AND METHODS}

\section{Sample's Collection}

The study area located in Malang, East java. Wild rats were obtained from various five sub districts in Malang: Lowokwaru, Klojen, Sukun, Blimbing, and Kedung Kandang. This procedure was conducted between August and September 2020. Rats were trapped using single live trap, which were made from metal $(15 \times 15 \times 30 \mathrm{~cm})$. On average 10 traps were set overnight per location. Captured rats were individually euthanazied by ketamine and xyllazine (AVMA, 2013). Samples of stools were taken from gastrointestinal tract. To obtain measurements and microphotographs of sporulated oocysts, three grams of feces were crushed to particles using mortar and mixed with $2.5 \%$ aqueous solution of potassium dichromate in petri dishes at room temperature $\pm 27^{\circ} \mathrm{C}$ for sporulation. The presence of parasites in collected faeces was examined microscopically by flotation method using a saturated salt solution (specific gravity=1.20). The flotations were screened for the presence of oocyst using Olympus CX-21 (Olympus Corporation, Tokyo, Japan) 400x magnification.

\section{Morphological analysis}

During microscopic analysis of oocysts isolated from rodents stools, multiple photomicrographs were taken at 400-1000 magnification using a microscope Olympus CX-21 (Olympus Corporation, Tokyo, Japan) and captured by Opti Lab Advanced Plus Camera (PT Miconos, Yogyakarta, Indonesia). Then parasite were measured using software ImageJ, data recorded in length and width of oocysts (in unsporulated and sporulated forms) and sporocysts (in sporulated forms). All measurements were mention in micrometers. The description of Eimeria sp. was based on measurements of sporulated oocysts (length and width), presence of micropyle, sporocysts, and oocysts shape. Additionally, main morphological traits (oocyst wall, polar granule, and Stieda body) were described according to the protocol of Duszynski and Wilber (1997).

\section{Geographical distribution of the Eimeria spp.}

Geographical Information Systems (GIS) maps were created using the QGIS Madeira 2020 long term release. The map was formed by adding the coordinates of the sampling points on the layers of geographic and administrative shape files. Shape files of 
the administrative boundaries and detailed rivers were derived from the Digital Elevation Model Nasional (DEMNAS) Indonesia.

\section{Statistical Analysis}

The analysis of morphological was carried out descriptively and data collected was analyzed using IBM SPSS (Statistic Package for Social Sciences) version 27 (IBM Corp., Armonk, New York). The chisquare test was used for comparison in assessing Eimeria infestation proportions per species and gender (Allam et.al., 2019).

\section{Ethics statements}

The present protocol was properly reviewed and approved by Animal care dan use Committee Universitas Brawijaya. The animal ethics approval numbers are 074-KEP-UB-2020.

\section{RESULTS AND DISCUSSION}

\section{Prevalence}

A total of 74 rodents were captured from five sub districts and ten sampling-localities in Malang city. Regarding the rodents' infection with Coccidia, 11 (14.9\%) were infected with Eimeria spp. Table 1 shows the distribution of Eimeria spp. infections according to the rodent species. In relation to study location, it was recorded that rodents in Lowokwaru (27.27\%), Kedungkandang (9.1\%), Klojen (36.36\%), Sukun (27.27\%) and Blimbing (0\%) were infected by Eimeria spp.

In Table 2, 3 (27.27\%) Rattus rattus showed positive infection, Rattus norvegicus recorded in 4 (36.36\%) , while Mus musculus and Suncus murinus, $\mathrm{o}(0 \%)$ and $4(36.36 \%)$ respectively. Furthermore, in Table 3, from 11 samples positive, 8 (72.72\%) of rodents infected were female and 3(27.27\%) were male.

Tabel 1 The Rat Positive Eimeria spp. relative to species, age and sex

\begin{tabular}{|c|c|c|c|c|c|c|c|c|c|c|}
\hline \multirow[t]{2}{*}{ Location } & & \multicolumn{4}{|c|}{ Rat species } & \multicolumn{2}{|c|}{ Sex } & \multicolumn{2}{|c|}{ Age } & \multirow[t]{2}{*}{$\begin{array}{c}\text { Eimeria spp } \\
\text { positive }\end{array}$} \\
\hline & & $\mathrm{Rr}$ & $\mathrm{Rn}$ & $\mathrm{Mm}$ & Sm & Male & Female & A & $\mathrm{J}$ & \\
\hline \multirow{2}{*}{ Lowokwaru } & $\mathrm{N}$ & 7 & 13 & 2 & 3 & 12 & 13 & 22 & 3 & 3 \\
\hline & $\%$ & 28 & 52 & 8 & 12 & 48 & 52 & 88 & 12 & 27.27 \\
\hline \multirow{2}{*}{ Klojen } & $\mathrm{N}$ & 6 & 10 & 0 & 3 & 9 & 10 & 11 & 8 & 4 \\
\hline & $\%$ & 31.58 & 52.63 & 0 & 15.79 & 47.36 & 52.63 & 57.89 & 42.11 & 36.36 \\
\hline \multirow{2}{*}{ Sukun } & $\mathrm{N}$ & 3 & 6 & 0 & 5 & 5 & 9 & 8 & 6 & 3 \\
\hline & $\%$ & 21.43 & 42.86 & 0 & 35.71 & 35.71 & 64.29 & 57.14 & 42.86 & 27.27 \\
\hline \multirow{2}{*}{ Blimbing } & $\mathrm{N}$ & 0 & 5 & 0 & 2 & 2 & 5 & 6 & 1 & 0 \\
\hline & $\%$ & 0 & 71.43 & 0 & 28.57 & 28.57 & 71.43 & 85.71 & 14.29 & 0 \\
\hline \multirow{2}{*}{ Kedungkandang } & $\mathrm{N}$ & 0 & 8 & 0 & 1 & 1 & 8 & 8 & 1 & 1 \\
\hline & $\%$ & 0 & 88.89 & 0 & 11.11 & 11.11 & 88.89 & 88.89 & 11.11 & 9.1 \\
\hline
\end{tabular}

Notes : Rr: Rattus rattus; Rn : Rattus norvegicus; Mm : Mus musculus; Sm: Suncus murinus; A: adult; J: Juvenile

Table 2 Eimeria spp. in wild rodents according to species of rats

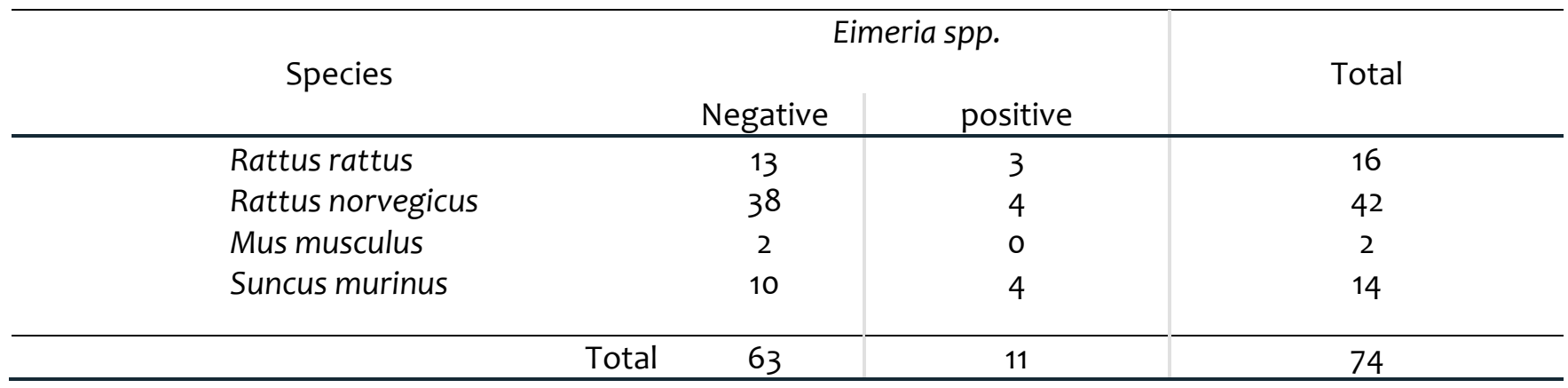


Statistical analysis showed no significant correlation between protozoa and species of the rodents $(P>0.05)$. However, significant results $(P<0.05)$ was found in protozoa infection and gender of rats.

\section{Identification and morphology of Eimeria spp.}

Shape-index (length/width ratio)

The ratio of length over width (shape-index) is used to demonstrate the shape of the oocysts and sporocysts. Sporulated oocysts are ellipsoidal, with a rough bilayer oocyst wall ( $1.1 \mu \mathrm{m}$ thick). Oocysts average length is $20.232 \mu \mathrm{m}$, and average width is $15.731 \mu \mathrm{m}$. Oocyst length-width ratios ranged from 1.0-1.5, with a mean of 1.28. Our microscopical data revealed two polar structures oocyst mycropyle. We found these structures in 11 investigated Eimeria species. The micropyle can be defined as a discontinuity in one of the layers of the oocyst wall (Mácová, 2013). Oocyst polar granule was present , while residuum and the micropyle-cap were absent.
Sporocysts are elongate-ovoid, wall thin, measured average length is $8.471 \mu \mathrm{m}$ and average width is $6.458 \mu \mathrm{m}$. Sporocyst length-width ratios ranged from 1.1-1.6, with a mean of 1.31. A thin convex Stieda body and indistinct substieda bodies were present and the sporocyst residuum was composed of numerous small granules less than $1.0 \mu \mathrm{m}$ in diameter dispersed randomly. Each sporocyst contained 2 sausage-shaped sporozoites in head-to-tail arrangement. The sporozoite nuclei were located centrally surrounded by refractile bodies (Figure 1).

\section{Geographical distribution}

According to the map in Figure 2, the Coccidia positive spots in Malang city based on the sampling areas which were spread in four sub districts. Through the coordinates recorded, Eimeria's points were distributed in the sub districts of Lowokwaru, Sukun, Klojen dan Kedung Kandang. Whereas in Blimbing were negative showed in black spot. In the

Table 3 Eimeria spp. in urban wild rodents according to gender of rats

\begin{tabular}{ccc|c|c}
\hline \multirow{2}{*}{ Gender } & \multicolumn{2}{c}{ Eimeria spp. } & Total \\
& & Negative & Positive & 30 \\
& Male & 22 & 8 & 44 \\
\hline Female & 41 & 3 & 74 \\
\hline
\end{tabular}
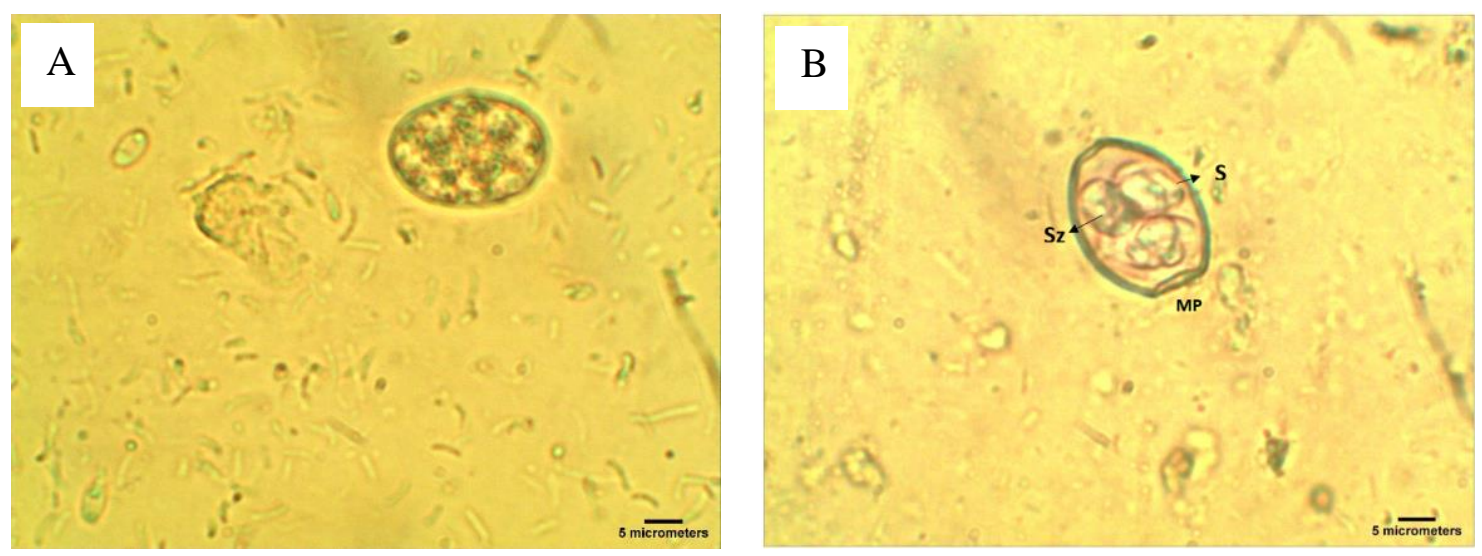

Figure $1 \mathrm{~A}$ photomicrograph of unsporulated oocyst of Eimeria spp. from Rattus norvegicus, scale bar $=5 \mu \mathrm{m}$. (B) A photomicrograph of sporulated oocyst of Eimeria spp. from Rattus norvegicus. The micro-pyle with no micropolar cap. Scale bar : $5 \mu \mathrm{m}$. Notes : S: sporocyst; Sz: sporozoite; MP: micro-pyle 
Table 4 Morphometric comparison between Eimeria spp. describe from species of rats

\begin{tabular}{|c|c|c|c|c|c|c|c|c|}
\hline \multirow[t]{3}{*}{ Rat's species } & \multicolumn{8}{|c|}{ Morphometric of Eimeria } \\
\hline & \multicolumn{2}{|c|}{ Oocyst $(\mu \mathrm{m})$} & \multicolumn{2}{|c|}{ Sporocyst $(\mu \mathrm{m})$} & \multirow{2}{*}{$\begin{array}{l}\text { Micro- } \\
\text { pyle }\end{array}$} & \multirow[t]{2}{*}{ Wall } & \multirow[t]{2}{*}{ Shape } & \multirow{2}{*}{$\begin{array}{l}\text { Stieda } \\
\text { of spo- } \\
\text { rocyst }\end{array}$} \\
\hline & Length & Width & Length & Width & & & & \\
\hline Rattus rattus & 22.164 & 16.168 & 9.010 & 7.669 & + & rough bilayer & ellipsoidal & + \\
\hline Rattus rattus & 21.792 & 15.851 & 8.274 & 6.536 & + & rough bilayer & ellipsoidal & + \\
\hline Rattus rattus & 20.123 & 15.740 & 9.797 & 7.075 & + & rough bilayer & ellipsoidal & + \\
\hline Rattus norvegicus & 21.930 & 16.408 & 8.644 & 5.721 & + & rough bilayer & ellipsoidal & + \\
\hline Rattus norvegicus & 17.383 & 14.772 & 7.437 & 6.290 & + & rough bilayer & ellipsoidal & + \\
\hline Rattus norvegicus & 20.216 & 17.774 & 9.333 & 6.564 & + & rough bilayer & ellipsoidal & + \\
\hline Rattus norvegicus & 22.363 & 17.196 & 10.107 & 6.321 & + & rough bilayer & ellipsoidal & + \\
\hline Suncus murinus & 21.804 & 16.199 & 8.800 & 6.941 & + & rough bilayer & ellipsoidal & + \\
\hline Suncus murinus & 18.065 & 15.555 & 7.870 & 5.582 & + & rough bilayer & ellipsoidal & + \\
\hline Suncus murinus & 18.843 & 14.020 & 7.444 & 6.453 & + & rough bilayer & ellipsoidal & + \\
\hline Suncus murinus & 17.872 & 13.165 & 6.467 & 5.891 & + & rough bilayer & ellipsoidal & + \\
\hline
\end{tabular}

picture, it can be seen that some Eimeria spp. points are located near rivers and some of them is densely populated settlements .

In this work, of total 74 rats stool samples, 11 (14.9\%) were infected with Eimeria spp., this is relatively lower than studied by Mácová et al. (2018) $32.7 \% \%$ in Europe based on coprological observation. The prevalence and intensity of infection could be influenced by season or weather of the year. Rehman et.al (2011) reported about significant raising of coccidiosis during the period of wet season in warmer climates. This phenomenon may be due to the stronger immunity of older rodents, however coccidiosis are in high case in young animals. The population of parasites in a certain host may be restricted by the host immunity.

The various factors that may influence the prevalence, such as hygiene, geographical and climatic conditions cannot be separated and attributed to varying prevalence in the different areas. Eimeria field populations are complex. The outcome of infection is influenced by the host, the parasite and environment condition (Jatau et.al.,2016). For further, research on the prevalence of Eimeria spp. in wild rodents is mostly investigated in Europe, while in Indonesia the study of this case is rare.

According Dubey et.al (2020), 1500 species have been described that infect a wide range of vertebrate hosts including mammals (rodents), birds, fish, reptiles and amphibians. Eimeria are with few exceptions, absolutely host-specific (Vrba et.al., 2015). From morphological characteristic in this study, it was suggesting coccidiosis caused by Eimeria nieschulzi. The recorded morphology and morphometric are closely similar with species described by Duszynski and Wilber (1997). Sporulated oocysts are ellipsoidal, with a rough bilayer wall, two polar structures oocyst mycropyle. Oocyst polar granule was present, while residuum and the micropyle-cap were absent. This species is one of rat-specific coccidian (Wiedmer et.al., 2020). E. nieschulzi is a common parasite in wild rodents, primarily in rats. Pathogenic effects of this coccidian are usually seen in young rats. In three species positive infection, there are no symptoms. However, another study showed, the symptoms of coccidiosis in rats are diarrhea, emaciation, and death in huge number of infection. Eimeria developing in villi of intestinal cell or lamina propria may cause severe coccidiosis (Šlapeta et al., 2001). Interestingly, E. nieschulzi may alter the host response to consequent infection with other parasites, such as nematodes or cestodes (Al-Dahwi et.al., 2006).

Diagnosis of Eimeria infection and identification is usually attempted by clinical signs in the host and biological features of the parasites. Hosts can be infected with multiple species and the oocysts of a single species often show variation in morphological characteristics used for differentiation, while some species share highly similar morphological characteristics (Zhao et al., 2001). Vice versa, three species of rats in this research were infected with same Eimeria spp. However, we recommend phylogenetic analysis for credible identification. The accurate identification has important implications for systematic taxonomy and phylogeny, population genetics, ecology and epidemiology) and diagnosis (Gasser and Chilton, 2001). 


\section{Geographical distribution of Eimeria spp. in Rodents in Malang City}

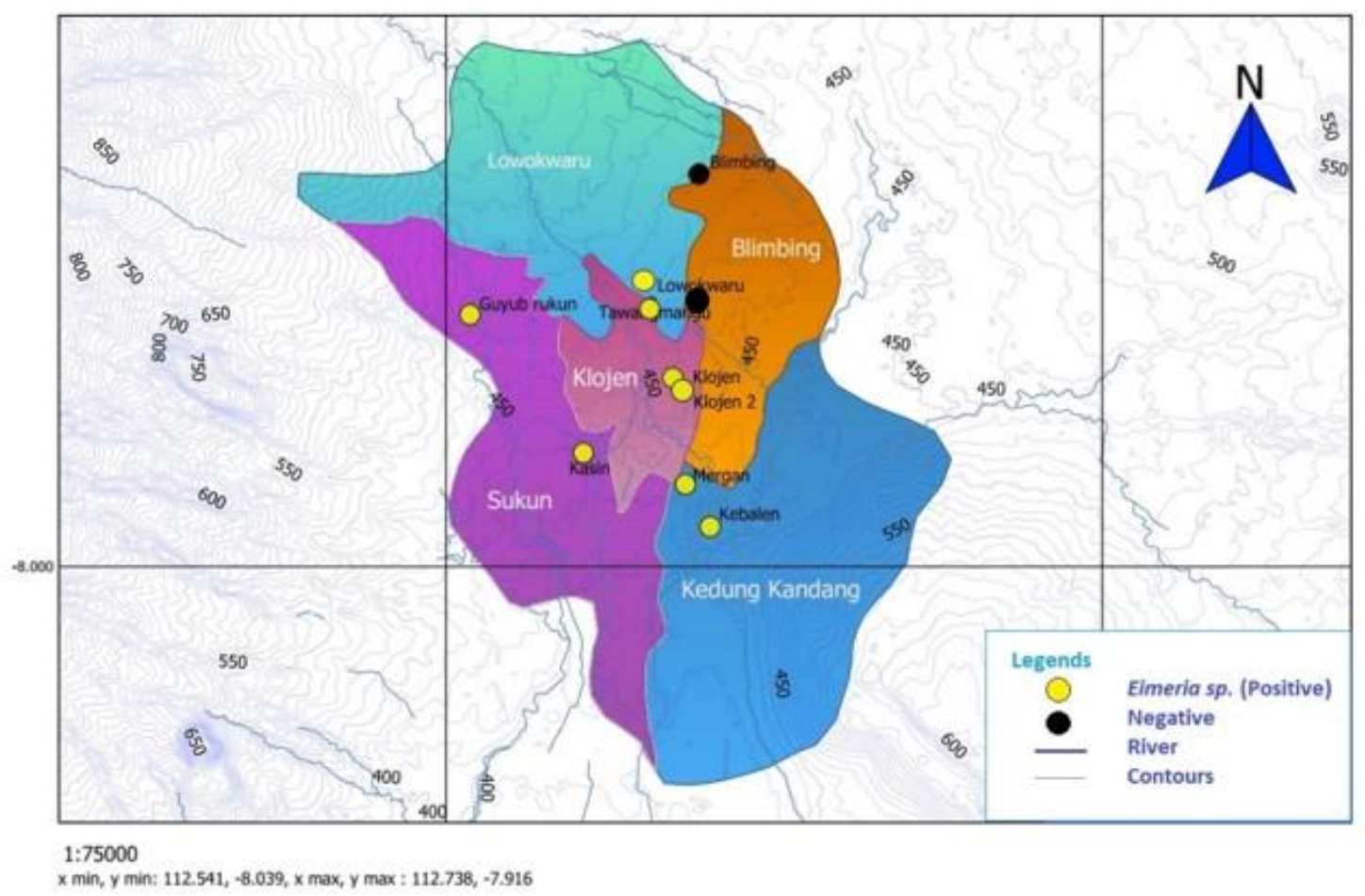

Figure 2 Geographic distribution of Eimeria spp. in rodents spread in 4 sub-district, Malang city. The yellow spot showed positive Eimeria spp in sampling area.

In addition, the geographical of Eimeria infection in rats were showed in 8 Sampling area, in Lowokwaru, Klojen, Kedung kandang and Sukun sub district. This study shows that infections with Eimeria spp. are ubiquitous in Malang city. Our GIS maps could serve as a guide to examine which areas are high risk. We argue that Eimeria in wildlife populations should be identified more frequently at the level of species previously described by taxonomists. Identification can play a fundamental role in knowledge and controlling, the appearance of genetic diversity for Eimeria. Geographical Information Systems (GIS) can be used to analyze differences in case factors, especially those related to geographical and environmental differences. Based on the spatial analysis there were cluster Eimeria in four sub districts in Malang city. Consequently, the knowledge of the bioecology of parasites, such as the biotic and abiotic factors that influence Eimeria prevalence. It is well understood that spatial distribution of parasites is influenced by abiotic and biotic environments, such as altitude, type of animal, age, human disturbance, geo-barriers, soil, and vegetation, and other factors (Acheson et al. 2015; Sun et al. 2018). Although our data are limited, we are convinced that the results acquired motivating the preventive strategies and measures designed to control parasite in endemic areas.

Our data showed, from 74 wild rodents, 11 (14.9\%) host were positive with coccidian protozoa. The species is suggested as Eimeria nieschulzi, one of rat-specific coccidian. However, the resolution using light microscopy is too low to conclusively confirm the presence or absence of such micro-pyle. Therefore, additional micrographs in higher resolution obtained by scanning electron microscopy, molecular markers and phylogenetic analysis are needed for credible morphological descriptions. The geographical distribution Eimeria's points were distributed in the districts of Lowokwaru, Sukun, Klojen dan Kedung Kandang. Our GIS maps could serve as a guide to examine which areas are high risk. We argue that Eimeria in wildlife populations should be identified more frequently at the level of species previously described by taxonomists. 


\section{ACKNOWLEDGEMENTS}

The authors gratefully acknowledge the financial support provided by Faculty of veterinary Medicine Universitas Brawijaya. The authors declare that they have no conflict of interest.

"All authors declare that there are no conflicts of interest".

\section{REFERENCES}

Acheson ES, Plowright AA, Kerr JT. 2015. Where have all the mosquito nets gone? Spatial modelling reveals mosquito net distributions across Tanzania do not target optimal Anopheles mosquito habitats. Malar J 14:322

Al-Dahwi, Z, Mayberry LF, Conder GA, bristol JR. 2006. Suppression of extraintestinal and intestinal Nippostrongylus brasilliensis induced eosinophilia by Eimeria nieschulzi. J.Parasitol., 92: 962-970.

Allam A, Eid SI, Adama KFAZ. (2019). Detection of parasites of Animal Health Importance Carried by wild rats collected from Jeddah city, Saudi Arabia. Ad anim vet Sci. 7(10):921-928.

Baker DG. 2016. Parasites in The Laboratory Rat (Second Edition). Elsivier

Baker DG. 2007 Flynn's Parasites of Laboratory Animals $2^{\text {nd }}$ edition. Ames, IA, Wiley-Blackwell.

Blake DG. 2015. Eimeria genomics: where are we now and where are we going? Vet. Parasitol. 212 (1-2), 68-74.

Brooks DR, Hoberg EP. 2000. Triage for the biosphere: the need and rationale for taxonomic inventories and phylogenetic studies of parasites. Comparative Parasitology 67, 1-25.

Chapman HD, Barta, JR, Blake D, Gruber A, Jenkins M, Smith NC, Suo X, Tomley FM. 2013. Chapter two - a selective review of advances in coccidiosis research.Adv. Parasitol. 83, 93-171

Chen $\mathrm{H}$, Wiedmer S, Hanig S, Entzeroth R, Kurth $\mathrm{M}$. 2013. 'Development of Eimeria nieschulzi (coccidia, apicomplexa) gamonts and oocysts in primary fetal rat cells', Journal of Parasitology Research, 2013(June).

Dubey JP. 2020. Coccidiosis in Livestock, Poultry, Companion Animals, and Humans; CRC Press, Taylor \& Francis Group: Boca Raton, FL, USA.

Duszynski DW, Wilber PG. 1997. A guidelines for the preparation of species description in the Eimeriidae. J. Parasitol. 83, 333-336.
Duszynski DW, Upton SJ. 2001: Cyclospora, Eimeria, Isospora, and Cryptosporidium spp. In: Samuel W. M., Pybus M. J., Kocan A. A. (Eds.): Parasitic Diseases of Wild Mammals, $2^{\text {nd }}$ Edition. Iowa State Press, lowa City, pp. 416-433

Gasser RB, Chilton NB. 2001. Applications of Singlestrand conformation polymorphism (SSCP) to taxonomy, diagnosis, population genetics and molecular evolution of parasitic nematodes. Vet.Parasitol., 101: 201-213.

Girard YA, Johnson CK, Fritz HM, Shapiro K, Packman AE, Melli AC, Carlson-Bremer D, Gulland FM, Rejmanek D, Conrad PA. 2016. Detection and characterization of diverse coccidian protozoa shed by California sea lions', International Journal for Parasitology: Parasites and Wildlife. Elsevier Ltd, 5(1), pp. 5-16.

Jansa SA, Weksler M. 2004: Phylogeny of muroid rodents: relationships within and among major lineages as determined by IRBP gene sequences. Mol. Phylogenet. Evol. 31: 256-276

Jarquín-Díaz VH, Ballard A, Jost J, Kraft J, Dikmen MN, Kvičerová J, Heitlinger E. 2019. Detection and quantification of house mouse Eimeria at the species level - Challenges and solutions for the assessment of coccidia in wildlife', International Journal for Parasitology: Parasites and Wildlife, 10(July), pp. 29-40.

Jatau, I.D.; Lawal, I.A.; Kwaga, J.K.; Tomley, F.M.; Blake, D.P.; Nok, A.J. 2016. Three operational taxonomic units of Eimeria are common in nigerian chickens and may undermine effective molecular diagnosis of coccidiosis. BMC Vet. Res., 12, 86.

Jeanes C, Vaughan-Higgins R, Green RE, Sainsbury AW, Marshall RN, Blake DP. 2013. Two new Eimeria species parasitic in corncrakes (Crex crex) (Gruiformes: Rallidae) in the United Kingdom. J. Parasitol. 99, 634-638.

Mácová BA. 2013. Phylogenetic relationships and population structure of coccidia in rodent families Muridae and Arvicolidae'

Mácová A, Hoblíková A, Hypša $V$, Stanko $M$, Martinů J, Kvičerová J. 2018. Mysteries of host switching: diversification and host specificity in rodentcoccidia associations. Mol. Phylogenetics Evol. 127, 179-189.

Rehman TU, Khan MN, Sajid MS, Abbas RZ, Arshad M, Iqbal Z, Iqbal A. 2011. Epidemiology of Eimeria and associated risk factors in cattle of district Toba Tek Singh, Pakistan. Parasitol Res 108:11711177 
Šlapeta JR, Modrý D, Votýpka J, Jirku M, Oborník M, Lukeš J, Koudela B. 2001. Eimeria telekii n.sp. (Apicomplexa: Coccidia) from Lemniscomys striatus (Rodentia: Muridae): Morphology, pathology and phylogeny', Parasitology, 122(2), pp. 133-143.

Soseco T. 2011. Pusat Pertumbuhan di Kota Malang: Potensi dan Permasalahan. Jurnal Ekonomi dan Studi Pembangunan. 3 (1): 1-25.

Sun P, Wronski T, Bariyanga JD, Apio A. 2018. Gastrointestinal parasite infections of Ankole cattle in an unhealthy landscape: an assessment of ecological predictors. Vet Parasitol 252:107-116

Turner WC, Versfeld WD, Kilian JW, Getz WM. 2012. Synergistic effects of seasonal rainfall parasites and demography on fluctuations in springbok body condition. J Anim Ecol. 81(1): 58-69

Vermeulen ET, Lott MJ, Eldridge MDB, Power ML. 2016. Evaluation of next generation sequencing for the analysis of Eimeria communities in wildlife', Journal of Microbiological Methods. Elsevier B.V., 124, pp. 1-9.

Vrba V; Pakandl M. 2015. Host specificity of turkey and chicken Eimeria: Controlled cross-transmission studies and a phylogenetic view. Vet. Parasitol. 208, 118-124.

Wiedmer S, Kurth T, Buder U, Bleischwitz S, Entezeroth R, Kurth M. 2020. Correlative light and electron microscopy of wall formation in Eimeria nieschulzi', Parasitology Research. Parasitology Research, 119(8), pp. 2667-2678.

Zhao X, Duszynski DW. 2001. Phylogenetic relationships among rodent Eimeria species determined by plastid ORF470 and nuclear 18S rDNA sequences. Int. J. Parasitol. 31, 715-719.

Zhao X, Duszynski DW. 2001. Molecular phylogenies suggest the oocyst residuum can be used to distinguish two independent lineages of Eimeria spp in rodents. Parasitol. Res. 87, 638-643.

Zhao X, Duszynski DW, Loker ES. 2001. Phylogenetic position of Eimeria antrozoi, a bat coccidium (Apicomplexa:Eimeriidae) and its relationship to morphologically similar Eimeria spp. from bats and rodents based on nuclear $18 \mathrm{~S}$ and plastid $23 \mathrm{~S}$ rDNA sequences. J. Parasitol. 87, 1120-1123 (PubMed ID: 11695377). 